\title{
The effect of two different types of electric current on experimental pain threshold in healthy individuals: A double blind, randomized controlled trial
}

\section{Sağlıklı bireylerde iki farklı elektrilk akımı tipinin deneysel ağrı eşiği üzerindeki etkisi: Çift kör randomize kontrollü çalışma}

\author{
Ayşe Numanoğlu Akbaş ${ }^{1}$, Sinem Suner Keklik ${ }^{1}$, Hatice Yakut ${ }^{2}$, Ömer Osman Pala ${ }^{1}$
}

${ }^{1}$ Cumhuriyet University, Health Sciences Faculty, Physical Therapy and Rehabilitation Department, Sivas, Turkey.

${ }^{2}$ SüleymanDemirel University, Health Sciences Faculty, Physical Therapy and Rehabilitation Department, Isparta, Turkey

Corresponding author: Ayşe Numanoğlu Akbaş, MD, Cumhuriyet University, Health Sciences Faculty, Physical Therapy and Rehabilitation Department, Sivas, Turkey

E-mail: aysenumanoglu@gmail.com

Received/Accepted: January 17, 2020 / May 11, 2020

Conflict of interest: There is not a conflict of interest.

\section{SUMMARY}

Objective: Physiotherapists often resort to electrophysical agents for pain management.

The aim of this study is to determine the effect of acupuncture-like Transcutaneous Electrical Nerve Stimulation (TENS) and Neuromuscular Electrical Stimulation (NMES) on experimental pressure pain threshold (PPT) in healthy individuals.

Method: Sixty one healthy participants (44 females, 17 males) aged 18-21 years were included in the study.The participants were divided into acupuncture-like TENS and NMES groups. The application was performed for 20 minutes from the right upper limb. The PPT changes of the participants were evaluated from the thenar part of both hands with an algometer before the current application, immediately after and 60 minutes after.

Results: There was no difference in the PPT levels of the right and left extremities of the participants in both groups before the application ( $>0.05)$. In both groups and intergroup comparisons, there was no difference in PPT levels measured from the right and left extremities of participants before the current application, immediately after and 60 minutes after the current application $(\mathrm{p}>0.05)$.

Conclusions: In this study, it was concluded that acupuncture-like TENS and NMES had no effect on experimental PPT and therefore, the clinical use of currents should be questioned.

Keywords: Electric stimulation therapy, pain, physical therapists, pressure.

\author{
Ayşe Numanoğlu Akbaş \\ (D) Sinem Suner Keklik \\ (iD) Hatice Yakut \\ (D) Ömer Osman Pala
}

ORCID IDs of the authors: A.N.A. 0000-0001-9296-8972 S.S.K. 0000-0002-9506-3172 H.Y. 0000-0002-0033-0144 Ö.O.P. 0000-0002-1826-5723

\section{ÖZET}

Amaç: Fizyoterapistler genellikle ağrı yönetimi için elektrofiziksel ajanlara başvurmaktadırlar. Bu çalışmanın amacı sağlıklı bireylerde akapunktur benzeri Transkutanöz Elektriksel Sinir Stimulasyonu (TENS) ve Nöromusküler Elektrik Stimulasyonunun (NMES) deneysel basınç ağrı eşiği (BAE) üzerindeki etkinliğinin belirlenmesidir. 
Yöntem: Çalışmaya 18-21 yaş arası 61 sağlıklı birey (44 kadın, 17 erkek) dâhil edildi. Katılımcılar akapunktur benzeri TENS ve NMES grubuna ayrıldı. Uygulama sağ üst ekstremiteden 20 dakika süreyle yapıldı. Katılımciların BAE değişimleri akım uygulamasından önce, hemen sonra ve 60 dakika sonra algometre ile her iki elin tenar bölgesinden değerlendirildi.

Bulgular: Her iki grupta yer alan bireylerin sağ ve sol ekstremitelerinin uygulama öncesi BAE düzeyleri arasında fark yoktu ( $p>0.05)$. Her iki grupta da ve gruplar arası karşılaştırmalarda uygulama öncesi, uygulamadan hemen sonra ve 60 dakika sonra sağ ve sol ekstremiteden ölçülen BAE düzeylerinde fark yoktu ( $p>0.05)$.

Sonuç: Bu çalışmada Akapunktur benzeri TENS ve NMES'in deneysel BAE üzerinde etkisi olmadığı bu nedenle akımların klinikteki kullanımlarının sorgulanması gerektiği sonucuna varılmıştır.

Anahtar sözcükler: Elektrik stimulasyon terapisi, ağrı, fizyoterapist, basınç

\section{INTRODUCTION}

Coping with pain is one of the main goals of physiotherapy and rehabilitation applications ${ }^{1}$. Physiotherapists often apply on electrophysical agents for pain management ${ }^{2}$.

The main purpose of physical therapy applications in pain management is to reduce pain severity, to increase pain threshold and tolerance by using different mechanisms ${ }^{3}$. It is seen that the factors such as preferences of physiotherapist and patient, available devices, contraindications of the patient are taken into consideration when choosing the types of electrical current in clinical applications for pain management ${ }^{4}$.

The electrical current most commonly used by physiotherapists to achieve the analgesic effect is Transcutaneous Electrical Nerve Stimulation (TENS) ${ }^{5}$. TENS is a simple and noninvasive modality used to reduce acute and chronic pain; is often preferred because it is cheap, safe, easy to use and has few side effects and drug interactions ${ }^{3,6}$. It has been hypothesized that different parameters will activate different inhibition mechanisms in TENS treatment and in parallel with that there may be changes in the start and duration of analgesia ${ }^{6-}$ ${ }^{8}$. Theoretically, it is assumed that TENS with high frequency-low intensity shows effect by the segmental pain inhibition process (gate control theory) and TENS with low frequency-high intensity shows effect by releasing of endogenous opioids (suprasegmental effect) 9. However, studies on this subject have not reached a definitive conclusion yet; many studies have indicated that there was no difference in terms of the effects of different TENS types. Despite this, there are also studies reporting that there are differences in terms of the effects of TENS applications with highfrequency or low-frequency ${ }^{10-14}$. The most effective combination of stimulation parameters in TENS treatment is still unknown ${ }^{15}$.

Neuromuscular Electrical Stimulation (NMES) is an electrostimulation technique used to achieve contraction in muscle through excitation of motor nerves ${ }^{8}$. The main uses of NMES are strengthening of muscles, prevention of muscle atrophy and degeneration, preservation or increase of joint range of motion ${ }^{7,16}$. However, the literature shows that NMES is also used for pain control in various pathologies ${ }^{17,18}$. Although there is a wide range of use in the clinic, it is reported that a stimulation frequency of $30-100 \mathrm{~Hz}$ and a phase time of $0.3 \mathrm{~ms}$ are effective in many applications ${ }^{8,16}$.

There are several studies in the literature examining the effects of different types of TENS on experimental pain ${ }^{19-21}$. There has been no study examining the effects of NMES on experimental pressure pain threshold. The aim of this study is to determine and compare the effectiveness of acupuncture-like TENS and NMES on experimental pressure pain threshold in healthy individuals.

\section{MATERIAL AND METHODS}

The participants of this study were selected on a voluntary basis from healthy individuals aged 1845 who had not received any diagnosis. Male and female individuals without any pathology causing acute or chronic pain in the musculoskeletal system, without sensory loss and not using analgesic or antidepressant drugs were included in the study. Individuals under the age of 18 and over 45 , women in the menstrual period or pregnant, individuals who fear from electrical stimulation, individuals with open wounds or skin lesions at the site of application, and individuals who had previously used TENS or NMES were not included in the study. Healthy volunteers were ensured from the acquaintances of the researchers as stated in the article published by Ring et al. ${ }^{22}$. The participants were informed about the study and written consent was obtained. The ethical aproval was obtained from the Clinical Studies Ethics Committee of Cumhuriyet University (Number: 2018-02/1). Experimental parts of the study were performed between September 2018-May 2019 at Cumhuriyet University, Faculty of Health Sciences, Department of Physiotherapy and Rehabilitation. Individuals were called once for evaluation and 
applications. The study is desinded as a duble blind randomized controlled trial.

Information about age, sex, height $(\mathrm{cm})$, body weight $(\mathrm{kg})$, dominant extremity, medical history of participants were recorded in the sociodemographic data form of the study. The subjects were divided into TENS (group 1) or NMES (group 2) groups according to their age and gender by using closed envelope technique.

\section{Evaluation of Experimental Pain Threshold}

Pain sensitivity against pressure of the participants was evaluated with an algometer. The algometer detects the intensity at which the feeling of pressure is felt as pain, a preferred method because it has good intra-observer and inter-observer reliability ${ }^{23}$, ${ }^{24}$. Algtech Commender Jtech Medical (JTECH MEDICAL INDUSTRIES, INC., Utah, USA) brand digital algometer was used for evaluation.
Participants were in a sitting position, the shoulders were at 30-degree abduction, the elbow was at 90degree flexion, the forearm was at supination, the wrist and the hand were at supporting position on the table. Measurements were made over the thenar area of both hands. The $1 \mathrm{~cm}^{2}$ probe of the algometer was positioned on a point marked previously, at a 90-degree angle with skin. Force was applied to the skin vertically with the probe and pressure pain threshold evaluation was done. Participants were asked to tell when they felt the pain first while being applied pressure with the algometer. The value in the digital indicator was read and recorded as Newtons. Measurement was made for each individual at three different times, immediately before electric current application, immediately after electric current application, 60 minutes after electric current application (Figure $1)$.

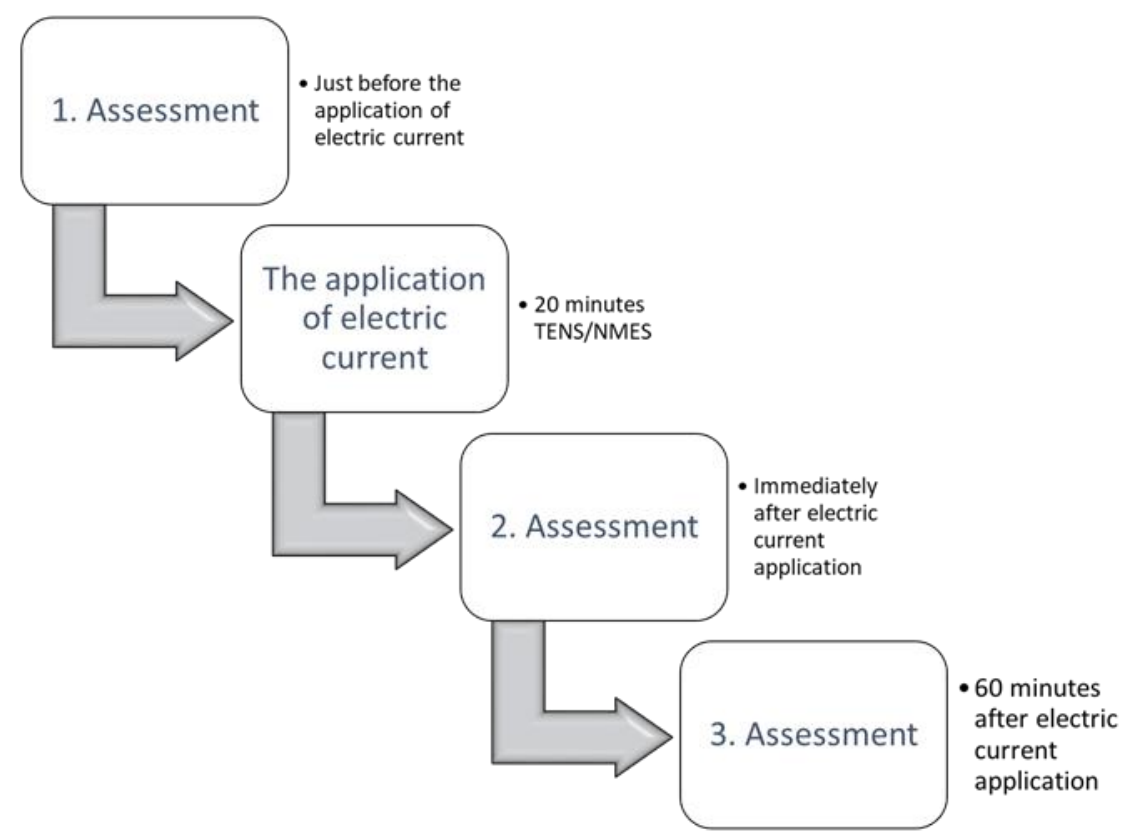

Figure 1: Experimental design

\section{Electric Current Application}

Acupuncture-like TENS and NMES were applied to the individuals who participated in the study. Electric current applications were made via the right hand; one of the electrodes was placed on the radial part of the wrist and the other on the proximal side of the second metacarpal. Two electrodes of square, self-adhesive, reusable, $5 \times 5$ $\mathrm{cm}^{2}$ were used for electrical current applications. Individuals were told that the electric current would turn on slowly and they were asked to tell the electric current where they felt strong but painless and comfortable. Electric current parameters were set to acupuncture-like TENS frequency: $2 \mathrm{MHz}$, current transition time: $170 \mu \mathrm{s}$, NMES frequency: $35 \mathrm{~Hz}$, phase time $250 \mu$ s work time: 8 sec, rest time: 8 sec. Each current application lasted 20 minutes. Electrical currents were generated by the Chattanooga Primera 
Portable Physical Therapy Device (DJO Global, California, USA).

Each experiment lasted an average of 85 minutes with 20-minute electric current applications and evaluations. Evaluations were made by a physiotherapist who was experienced in this field but had no knowledge of the study. Electric current applications were performed by another experienced physical therapist. The participants were unaware of what type of electric current was applied to them.

\section{Statistical Analysis}

Power analysis was performed using Pass (Power and Sample, 2008) program to determine the sample size to be included in the study. The testing power was found to be as $\mathrm{P}=0.80775$ when $\alpha=$ $0.05, \beta=0.20$ and $1-\beta=0.80$. It was determined that a total of 50 individuals should be included in the study. The study was completed with 61 subjects and post hoc power analysis was found to be as 0.97236. SPSS ${ }^{\circledR}$ program version 22 (Statistical Package for Social Sciences, IBM Corp., Armonk, NY, USA) was used to analyze the obtained data. Mean and standard deviation values were used for continuous variables (quantitative) obtained with measurements, and number and percentage values were used for categorical variables (qualitative). Kolmogorov Smirnov test, Skewness-Kurtosis index and graphical methods were used to examine the suitability of quantitative variables for the normal distribution. On the comparison of the differences of intergroup and the differences regarding the measurements taken at different times (delta values), Student's independent sample t-test was used for the normally distributed variables and Mann-Whitney $\mathrm{U}$ test was used for non-normally distributed variables. Whether the changes in the measurements taken at different times in each group were significant and for non-normally distributed variables, Bonferroni corrected Fridman test was used. The significance level for this study was accepted as $\mathrm{p}<0.05$.

\section{RESULTS}

The study was conducted with the participation of 63 healthy young adult individuals, 44 of whom were female $(69.85 \%)$ and 19 of whom were male (30.15\%), who met the inclusion criteria. Two male individuals could not complete the application. Participants were divided into two groups as TENS (group 1, n = 33) and NMES (group 2, n= 28). Demographic characteristics of the individuals were shown in Table 1. There was no statistically significant difference in comparison of physical characteristics of each group such as age, height, body weight, and body mass index ( $p>0.05$ ).

The values of the pain threshold measurements were calculated before, immediately after and 60 minutes after the application. There was no statistically significant difference in both TENS (right side $\mathrm{p}=0.060$ and left side $\mathrm{p}=0.109$ ) and NMES (right side $\mathrm{p}=0.267$ and left side $\mathrm{p}=0.409$ ) groups (Table 2,3 ).

Table 1: Demographic Characteristics of the Participants

\begin{tabular}{|l|l|l|l|}
\hline \multirow{2}{*}{ Age $($ year$)$} & Group 1 $(\mathrm{n}=33)$ & Group 2 $(\mathrm{n}=28)$ & \multirow{2}{*}{$\mathrm{p}$} \\
\cline { 2 - 3 } & Mean \pm SD & Mean \pm SD & \\
\hline Height $(\mathrm{cm})$ & $19.69 \pm 1.15$ & $19.92 \pm 0.85$ & $0.173+$ \\
\hline Body Weight $(\mathrm{kg})$ & $167.30 \pm 8.97$ & $167.25 \pm 10.33$ & $0.986^{\S}$ \\
\hline Body massindex & $64.66 \pm 12.42$ & $60.69 \pm 10.70$ & $0.191^{\S}$ \\
\hline Dominant Side & $23.02 \pm 3.56$ & $21.75 \pm 3.38$ & $0.089+$ \\
\hline Right & & & \\
\hline Left & $31(\% 93.9)$ & $24(\% 85.7)$ & \\
\hline Sex & $2(\% 6.1)$ & $4(\% 14.3)$ & \\
\hline Female & & & \\
\hline Male & $24(\% 72.7)$ & $20(\% 71.4)$ & \\
\hline
\end{tabular}

TENS: Transcutaneous Electrical Nerve Stimulation, NMES: Neuromuscular Electrical Stimulation, SD: Standart Deviation, ${ }^{\S}$ Student $\mathrm{t}$ test, +Mann-Whitney U test

Table 2: Changes with the application of electric current for the right upper extremity. 


\begin{tabular}{|l|l|l|l|l|}
\hline & IAA - BA & $60 \mathrm{mn}-\mathrm{BA}$ & $60 \mathrm{mn}-$ IAA & \multirow{2}{*}{$\mathrm{p}^{*}$} \\
\cline { 2 - 5 } & Mean $\pm \mathrm{SD}$ & Mean $\pm \mathrm{SD}$ & Mean \pm SD & \\
\hline Group 1 $(\mathrm{n}=33)$ & $-1.84 \pm 10.93$ & $-8.17 \pm 15.73$ & $-6.32 \pm 12.21$ & 0.060 \\
\hline Group 2 $(\mathrm{n}=28)$ & $-2.55 \pm 12.84$ & $-7.99 \pm 17.55$ & $-5.43 \pm 13.98$ & 0.267 \\
\hline $\mathrm{p}+$ & 0.919 & 0.845 & 0.811 & \\
\hline
\end{tabular}

BA: Before application, IAA: immediately after application, 60mn: 60 minutes after application, TENS: Transcutaneous Electrical Nerve Stimulation, NMES: Neuromuscular Electrical Stimulation, SD: Standart Deviation, ${ }^{*}$ Friedman test, +Mann-Whitney U test

Table 3: Changes with the application of electric current for the left upper extremity.

\begin{tabular}{|l|l|l|l|l|}
\hline & IAA - BA & $60 \mathrm{mn}-\mathrm{BA}$ & $60 \mathrm{mn}-$ IAA & \multirow{2}{*}{$\mathrm{p}^{*}$} \\
\cline { 2 - 5 } & Mean \pm SD & Mean \pm SD & Mean \pm SD & \\
\hline Group 1 $(\mathrm{n}=33)$ & $1.34 \pm 10.53$ & $-4.73 \pm 15.65$ & $-6.08 \pm 14.08$ & 0.109 \\
\hline Group 2 $(\mathrm{n}=28)$ & $-2.72 \pm 9.29$ & $-5.96 \pm 15.14$ & $-3.24 \pm 14.57$ & 0.409 \\
\hline p+ & 0.086 & 0.806 & 0.563 & \\
\hline
\end{tabular}

BA: Before application, IAA: immediately after application, 60mn: 60 minutes after application, TENS: Transcutaneous Electrical Nerve Stimulation, NMES: Neuromuscular Electrical Stimulation, SD: Standart Deviation, *Friedman test, +Mann-Whitney U test

Repeated measurements for TENS and NMES groups were compared. The change between measurements performed before, immediately after and 60 minutes after the application was not statistically different for both the right (respectively: $\mathrm{p}=0.919 ; \mathrm{p}=0.845 ; \mathrm{p}=0.811$ ) and left sides (respectively: $\mathrm{p}=0.086 ; \mathrm{p}=0.806 ; \mathrm{p}=0.563$ ) (Table 2, 3).

\section{DISCUSSION}

In this study which was planned using experimental pain threshold method on healthy persons, there was no statistically significant difference between experimental pressure pain measurements performed from the ipsilateral and contralateral side in groups which TENS or NMES currents were applied. Best of our knowledge this is the first study comparing the TENS and NMES current parameters in terms of evaluation of the pain threshold with experimental pain method in healthy individuals.

In the study, it was observed that the application of TENS did not cause a significant change in pressure pain threshold for young individuals; it has been found that the low frequency TENS does not have the hypoanalgesic effect seen in the pain reduction mechanism by activation of depolarization of $\mathrm{A}$ delta and $\mathrm{C}$ fibers and pain modulation mechanisms resulting from brain stem 25,26 . It is seen that there are conflicting results regarding the effects of TENS on experimental pain threshold when the literature is examined.

In a study on rats, it has been indicated that TENS activates different neuropharmacological mechanisms in the central nervous system. It has been reported that low-frequency TENS $(4 \mathrm{~Hz})$ significantly increases serotonin concentrations during and immediately after treatment, while high-frequency TENS $(100 \mathrm{~Hz})$ does not cause any change ${ }^{27}$. Contrary to this, it was found in another study that high-frequency TENS $(80 \mathrm{~Hz})$ applied at strong but painless intensity level caused a greater increase in pain threshold than the painless but lowfrequency TENS $(3 \mathrm{~Hz})^{28}$. The effects of high $(110$ $\mathrm{Hz})$ and low-frequency $(4 \mathrm{~Hz})$ TENS on mechanical pain threshold for young individuals were examined in a study that was structurally similar but yielded opposite results to this study. The study, by Chesterton et al., has found that both TENS types reduced pain by raising the threshold value ${ }^{15}$. Chen and Johnson have found that highfrequency TENS $(80 \mathrm{~Hz})$ applied at strong but painless intensity level caused a greater increase in mechanical pain threshold than low-frequency TENS $(3 \mathrm{~Hz})^{28}$. Macedoet al. reported that there was no difference in pain threshold values in the group applied conventional TENS $(100 \mathrm{~Hz})$ at the sensory level, however, the pain threshold of the group which was applied burst-TENS (carrier frequency of $100 \mathrm{~Hz}$ burst-modulated at $4 \mathrm{~Hz}$ ) at 
the motor level pain threshold were increased ${ }^{21}$. The studies of Solomon et al. have also shown that high-frequency TENS $(100 \mathrm{~Hz})$ application did not cause a change in pain threshold ${ }^{29}$.

TENS applied at sensory intensity, which was one of the TENS applications with 4 levels of stimulation intensity such as Subsensory, Sensory, Motor and Noxious, has been reported to be more used in clinics and studies ${ }^{30}$. In a systematic review involving 13 studies, it was reported that evidence from experimental pain researches showed that the pulse frequency in TENS did not affect hyperalgesia when the pulse intensity, the pulse pattern and the pulse duration were kept constant. Only three studies showed statistically significant differences between frequencies and pain results ${ }^{31}$. In these studies, the superiority of $100 \mathrm{~Hz}$ on $10 \mathrm{~Hz}$ [32], 5 and $80 \mathrm{~Hz}$ on $2 \mathrm{~Hz}$ [33], $4 \mathrm{~Hz}$ on $110 \mathrm{~Hz}$ [34] was shown, but it was argued that insufficient sample sizes in the relevant studies may have revealed false and negative findings ${ }^{31}$. In the study of Bergeron-Vé zina et al. ${ }^{35}$, it was reported that high and low frequency TENS applications in young individuals caused a strong and significant decrease in experimental heat pain.

Tanaka et al., compared low-frequency TENS applications ( $10 \mathrm{~Hz}$ frequency, $500 \mu$ s pulse width) at two different intensity levels (sensory/motor). Tanaka et al., has reported that low-frequency TENS applied at the sensory level did not cause a significant change in pain thresholds before, during and after application, and similarly to this study, the pain threshold was gradually decreased. It has been also found that TENS applied at highintensity motor level created a significant increase in pain threshold ${ }^{36}$.

In another study examining the effects of doserelated TENS, it has been found that TENS applied at a dose below the sensory threshold would not cause hypoalgesia. It has also been detected that an increase in the pain threshold would occur at a strong but tolerable painless dose ${ }^{37}$. According to a review in 2008, it has been concluded that TENS frequencies could not affect hypoalgesia by using experimental pain models in healthy individuals ${ }^{38}$. In the review examining the efficacy of TENS in experimental pain studies, it has been concluded that only conventional TENS would cause changes in the pain threshold ${ }^{20}$. Contradictory results were also obtained in experimental pain models of lowfrequency and tolerable TENS used in this study. This result shows that the intensity is more important than the frequency in terms of pain modulation when associates with the relevant literature.
Although very few studies have been made in this area, it has been recommended that the users of TENS should choose an intensity and frequency settings based on the comfort of the stimulation rather than the analgesic effect. It has been found that there is too much interpersonal variation in the parameters chosen by the users of TENS for a long period of time ${ }^{39}$. The TENS parameters used in the studies are based on the use of subjective definitions of intensity. The applied intensity can be influenced by many factors such as electrode size, skin permeability and individual sensitivity. Future studies may aim to find dose-dependent responses of TENS in healthy group and experimental pain methods.

The hypoalgesic effect of TENS has also been investigated clinically in the painful population; negative and positive effects have been obtained. In a relevant Cochrane review, it has been reported that there was a lack of methodological accuracy or valid reporting to make reliable assessments of the role of TENS in chronic pain management ${ }^{40}$. It has been seen that the literature about TENS presented very complex and different results. This situation may be due to the fact that there are many different parameters related to the current application such as frequency, intensity, duration time, evaluation method, population, or comparison difficulties may occur due to the differences in experimental methods. Considering that pain is a highly subjective phenomenon, it is difficult to reach a clear conclusion. It has been reported that parameter combinations involving the stimulation area might play an important role in the pain modulation obtained in an experimental pain model, and therefore it was possible that popular TENS models used clinically did not always produce optimal hypoalgesic effects ${ }^{15}$. For this reason, more research about the stimulation area and intensity levels are required.

In this study, PPT measurements were performed from the contralateral side as well as the ipsilateral side with the idea that current application would not only produce a local response but also a systemic pain modulating response. Measurements in the study of Tanaka et al. have been recorded from the contralateral rather like in this study. Although there was no difference between the measurements in this study, the study of Tanaka et al. showed that the pain threshold at the contralateral side increased with low-frequency TENS applied at the motor level. This situation was attributed to segmental inhibition of TENS as well as to the systemic pain modulation responses of TENS ${ }^{36}$. 
It has been observed that the differences in pain threshold values obtained immediately after the application were few in the study. But sensitization occurred at the application site after 60 minutes and the differences in pain threshold scores widened more. This showed that pain inhibition mechanisms lost their effect until this time. However, in the studies of Slukaet al., it has been shown that neurotransmitters continued to be released from the spinal cord during 20-minute of TENS application ${ }^{27,41}$. It has been indicated that TENS stimulation periods should be longer than 20 minutes to increase the effect ${ }^{15}$.

In a study of Kulcu et al. ${ }^{42}$, conventional physical therapy (including TENS) and exercise programs were applied to a group of patients with knee osteoarthritis, while the other group received NMES in addition to this. Although there was a decrease in pain in both groups, it was shown that the groups were not superior to each other. It can be considered that NMES, which is used for muscle strengthening with the recovery effect functionally, can be used in clinics in terms of pain inhibition. It is stated that this change caused by NMES in pain is not due to an increase in muscle strength rather this change is attributed to the stimulation of afferent nerve fibers that inhibit neurons which makes synapses in the dorsal horn by transcutaneous electric current or the increase in the release of endogenous opioids due to NMES application ${ }^{18}$. Contrary to this, the opinion is present in the literature that NMES has the basic limitation of creating discomfort during application 43,44 .

\section{Limitations}

In this study, experimental pain experience was used instead of the clinical pain experience. It has been observed that sensitivity occurred in the evaluation area due to repeated pain evaluations with PPT. The subjects stated this during the experiment. It was thought that this situation might mask the changes in pain threshold due to tissue sensitization.

\section{CONCLUSION}

Best of our knowledge this is the first study to compare the effect of TENS and NMES currents on the pain threshold from the ipsilateral and contralateral sides by using the experimental pain method. In the literature, the importance of TENS intensity to create maximal hypoalgesia with experimental pain in asymptomatic healthy individuals is emphasized. There were no significant differences in the tolerable intensity level used for low-frequency TENS and NMES currents before and after stimulation. However, hypersensitivity was clinically observed in individuals due to individual sensitivity. Although TENS is a noninvasive, inexpensive, reliable and easy to use electrophysical agent that is frequently used in acute and chronic painful situations, these contradictions in research emphasize the necessity of using this current more carefully in the clinic and question its effects.

Acknowledgements: Some of the data of this study was presented as oral presentation at the 7 . National Physiotherapy and Rehabilitation Congress.

Declerationt of Interest: The authors report no conflicts of interest.

Funding: This work is supported by the Scientific Research Project Fund of Sivas Cumhuriyet University under the project number SBF-66.

Ethical Approval: The study was approved by the Clinical Studies Ethics Committee of Cumhuriyet University (Number: 2018-02/1).

Informed Consent: Written informed consent was obtained from all study participants.

\section{REFERENCES}

1. Mittrach R, Grill E, Walchner-Bonjean M, Scheuringer M, Boldt C, Huber EO, Stucki, G. Goals of physiotherapy interventions can be described using the International Classification of Functioning, Disability and Health. Physiother. 2008;94:150-7.

2. Ginnerup-Nielsen E, Christensen R, Thorborg K, Tarp S, Henriksen M. Physiotherapy for pain: a meta-epidemiological study of randomised trials. $\mathrm{Br} \mathbf{J}$ Sports Med. 2016;50:965-71.

3. Fırat T, Meriç A, Kırdı N. Magnetoterapi ve ultrason uygulamalarının deneysel ağrı üzerine etkilerinin karşılaştırılması: tek kör klinik çalışma. Türk Fizyoterapi ve Rehabilitasyon Dergisi. 2009;20:178-83.

4. Springer S, Laufer Y, Elboim-Gabyzon M. Clinical decision making for using electrophysical agents by physiotherapists, an Israeli survey. Israel journal of health policy research. $2015 ; 4: 14$.

5. Johnson MI. Pain Management and Clinical Effectiweness of TENS. Crit Rev Phys Rehabil Med. 2017;29:1-4

6. McDenough S. Neuromuscular and Muscular Electrical Stimulation. Watson T. (Eds.) Electrotherapy E-Book: evidence-based practice. 12th Ed. Philedelphia: Elsevier Health Sciences; 2008; pp 231-252 
7. Kırdı N. Nöromusküler Elektrik Stimulasyonu. Şimşek N, Kırdı N. (Eds.) Elektroterapide Temel Prensipler ve Klinik Uygulamalar. 1st Ed. Ankara: Pelikan Yayıncılık; 2015; pp 119126.

8. Baydoğan Arman N. Nöromusküler Elektriksel Stimulasyon. Razak Özdinçler A. (Eds.) Fiziksel Modaliteler ve Elektroterapi. 1st ed. İstanbul: İstanbul Medikal Sağlık ve Yayıncılık Hiz. Tic. Ltd. Şti; 2014; pp 139-148.

9. Walsh DM, McAdams ET.(Eds.) TENS: clinical applications and related theory: New York : Churchill Livingstone, 1997.

10.Grimmer K. A controlled double blind study comparing the effects of strong burst mode TENS and high rate TENS on painful osteoarthritic knees. Aust J Physiother. 1992;38:49-56.

11.Jensen H, Zesler R, Christensen T. Transcutaneous electrical nerve stimulation (TENS) for painful osteoarthrosis of the knee. Int J Rehabil Res. 1991;14:356-8.

12.Tulgar M, McGlone F, Bowsher D, Miles JB. Comparative effectiveness of different stimulation modes in relieving pain. Part II. A double-blind controlled long-term clinical trial. Pain. 1991;47:157-62.

13.Tulgar M, McGlone F, Bowsher D, Miles JB. Comparative effectiveness of different stimulation modes in relieving pain. Part I. A pilot study. Pain. 1991;47:151-5.

14.Köke AJ, Schouten JS, Lamerichs-Geelen MJ, Lipsch JS, Waltje EM, van Kleef M, et al. Pain reducing effect of three types of transcutaneous electrical nerve stimulation in patients with chronic pain: a randomized crossover trial. Pain. 2004;108:36-42.

15.Chesterton LS, Barlas P, Foster NE, Lundeberg T, Wright CC, Baxter GD. Sensory stimulation (TENS): effects of parameter manipulation on mechanical pain thresholds in healthy human subjects. Pain. 2002;99:253-62.

16.Boyaci A. Nöromusküler Elektriksel Stimülasyon. Turkiye Klinikleri Journal of Physical Medicine Rehabilitation Special Topics. 2015;8:44-50.

17.Renzenbrink GJ, Ijzerman MJ. Percutaneous neuromuscular electrical stimulation (P-NMES) for treating shoulder pain in chronic hemiplegia. Effects on shoulder pain and quality of life. Clin. rehabil. 2004;18:359-65.
18. Gaines JM, Metter EJ, Talbot LA. The effect of neuromuscular electrical stimulation on arthritis knee pain in older adults with osteoarthritis of the knee. Appl Nurs Res. 2004;17:201-6.

19. Chen CC, Johnson MI. An Investigation Into the Effects of Frequency-Modulated Transcutaneous Electrical Nerve Stimulation (TENS) on Experimentally-Induced Pressure Pain in Healthy Human Participants. Journal of Pain. 2009;10:1029-37.

20.Claydon LS, Chesterton LS, Barlas P, Sim J. Dose-specific effects of transcutaneous electrical nerve stimulation (TENS) on experimental pain: a systematic review. Clin J Pain. 2011;27:635-47.

21. Macedo LB, Josue AM, Maia PH, Camara AE, Brasileiro JS. Effect of burst TENS and conventional TENS combined with cryotherapy on pressure pain threshold: randomised, controlled, clinical trial. Physiotherapy. 2015;101:155-60.

22.Ring IJ, Markström A, Bazargani F, Nevéus T. Sleep disordered breathing in enuretic children and controls. J Pediatr Urol. 2017;13: e1-. e6.

23.Kinser AM, Sands WA, Stone MH. Reliability and validity of a pressure algometer. J Strength Cond Res. 2009;23:312-4.

24. Chesterton LS, Sim J, Wright CC, Foster NE. Interrater reliability of algometry in measuring pressure pain thresholds in healthy humans, using multiple raters. Clin J Pain 2007;23:7606.

25.Willer J, Bouhassira D, Le DBJNcCn. Neurophysiological bases of the counterirritation phenomenon: diffuse control inhibitors induced by nociceptive stimulation. Clin Neurophysiol. 1999;29:379-400.

26. Marchand S. The phenomenon of pain: Lippincott Williams \& Wilkins; 2015.

27. Sluka KA, Lisi TL, Westlund KN . Increased release of serotonin in the spinal cord during low, but not high, frequency transcutaneous electric nerve stimulation in rats with joint inflammation. Arch Phys Med Rehabil. 2006;87:1137-40.

28. Chen C-C, Johnson MI. An investigation into the hypoalgesic effects of high-and lowfrequency transcutaneous electrical nerve stimulation (TENS) on experimentally-induced blunt pressure pain in healthy human participants. J Pain. 2010;11:53-61. 
29.Solomon J, Shebshacvich V, Adler R, Vulfsons $\mathrm{S}$, Rosenbach A, Eisenberg E. The effects of TENS, heat, and cold on the pain thresholds induced by mechanical pressure in healthy volunteers. Neuromodulation. 2003;6:102-7.

30.Manal TJ, Snayder-Mackler L. Electrical Stimulation for Pain Modulation. Robinson AJ. (Eds.) Clinical electrophysiology: electrotherapy and electrophysiologic testing. 3 rd ed. Philedelphia; Lippincott Williams \& Wilkins; 2008; pp 151-196.

31.Chen C-C, Tabasam G, Johnson MI. Does the pulse frequency of transcutaneous electrical nerve stimulation (TENS) influence hypoalgesia?: A systematic review of studies using experimental pain and healthy human participants. Physiother. 2008;94:11-20.

32.de Tommaso M, Fiore P, Camporeale A, Guido M, Libro G, Losito L,Megna M, Puca F, Megna G. High and low frequency transcutaneous electrical nerve stimulation inhibits nociceptive responses induced by $\mathrm{CO} 2$ laser stimulation in humans. Neurosci Lett. 2003;342:17-20.

33. Chakour M-C, Gibson S, Neufeld M, Khalil Z, Helme RD. Development of an active placebo for studies of TENS treatment. Proceedings of the 9th World Congress on Pain. 2000;16:98792.

34. Walsh DM, Liggett C, Baxter D, Allen JMJP. A double-blind investigation of the hypoalgesic effects of transcutaneous electrical nerve stimulation upon experimentally induced ischaemic pain. Pain Res. 1995;61:39-45.

35.Bergeron-Vézina K, Corriveau H, Martel M, Harvey M-P, Léonard G. High-and lowfrequency transcutaneous electrical nerve stimulation does not reduce experimental pain in elderly individuals. Pain. 2015;156:2093-9

36. Tanaka $\mathrm{K}$, Ikeuchi $\mathrm{M}$, Izumi $\mathrm{M}$, Aso $\mathrm{K}$, Sugimura N, Enoki H, Nagano Y, Ishida K, Tani T. Effects of two different intensities of transcutaneous electrical nerve stimulation on pain thresholds of contralateral muscles in healthy subjects. J Phys Ther Sci.2015;27:27714.

37.Moran F, Leonard T, Hawthorne S, Hughes CM, McCrum-Gardner E, Johnson MI, Rakel BA, Sluka KA, Walsh DM. Hypoalgesia in response to transcutaneous electrical nerve stimulation (TENS) depends on stimulation intensity. J Pain. 2011;12:929-35.

38.Claydon L, Chesterton L. Does transcutaneous electrical nerve stimulation (TENS) produce'dose-responses'? A review of systematic reviews on chronic pain. Phys Ther Rev. 2008;13:450-63.

39.Johnson M, Ashton C, Thompson J. The consistency of pulse frequencies and pulse patterns of transcutaneous electrical nerve stimulation (TENS) used by chronic pain patients.Pain. 1991;44:231-4.

40.Nnoaham KE, Kumbang J. Transcutaneous electrical nerve stimulation (TENS) for chronic pain. Cochrane Database Syst Rev. 2008(3).

41.Sluka K, Vance C, Lisi T. High-frequency, but not low-frequency, transcutaneous electrical nerve stimulation reduces aspartate and glutamate release in the spinal cord dorsal horn. J. Neurochem.2005;95:1794-801.

42.Kulcu DG, Yanik B, Gulsen G, Gokmen D. Effect of Neuromuscular Electrical Stimulation on Pain and Functional Parameters in Knee Osteoarthritis. Turkish Journal of Physical Medicine and Rehabilitation. 2009;55:111-5.

43.Naaman SC, Stein RB, Thomas C. Minimizing discomfort with surface neuromuscular stimulation. Neurorehabil Neural Repair. 2000;14:223-8.

44.Laufer Y, Tausher H, Esh R, Ward AR. Sensory transcutaneous electrical stimulation fails to decrease discomfort associated with neuromuscular electrical stimulation in healthy individuals. Am J PHYS Med Rehabil. 2011;90:399-406. 